\title{
EFEKTIFITAS BELAJAR-MENGAJAR BAHASA YUNANI KOINE PADA PANDEMI COVID-19
}

\author{
Adi Putra, M.Th. \\ Sekolah Tinggi Teologi Pelita Dunia Tangerang \\ addiepoetra7@gmail.com
}

\section{A. Pendahuluan}

Setiap guru atau dosen menginginkan setiap ilmu yang disampaikan kepada siswa atau mahasiswanya dapat dipahami dengan baik. Sehingga proses transfer pengetahuan dapat berjalan dengan baik. Itulah sebabnya setiap guru atau dosen dengan sungguh-sungguh dan serius mempersiapkan kelas atau mata kuliah yang diampunya. Mulai dari materi hingga kepada metode atau pendekatan mengajar yang dipilih supaya belajar-mengajar dapat berjalan dengan efektif. Tuti Waty Boang Manalu, Christina Metallica Samosir, Ronny Gunawan mengatakan,

"Persiapan mengajar merupakan upaya untuk memperkirakan tindakan yang akan dilakukan dalam kegiatan pembelajaran. Sebagaimana diketahui bahwa sebelum melaksanakan kegiatan pembelajaran di kelas, banyak hal yang perlu di persiapkan oleh seorang guru. Hal paling mendasar bagi guru dalam melaksanakan kegiatan pembelajaran adalah menyiapkan perangkat pembelajaran sebagai rambu-rambu yang dijadikan acuan dalam pelaksanaan pembelajaran di kelas. Adapun hal-hal yang perlu dipersiapkan guru sebelum melaksanakan pembelajaran di kelas antara lain adalah silabus, Rencana Pelaksanaan Pembelajaran (RPP) dan materi ajar. Selain mempersiapkan administrasi pembelajaran guru juga harus dapat memilih metode, pendekatan, media pembelajaran dan sumber belajar lainnya guna menunjang kelangsungan pelaksanaan pembelajaran"(Tuti Waty Boang Manalu, 2019: 111-123).

Berdasarkan pendapat di atas, maka dapat dikatakan bahwa efektifitas sebuah proses belajar-mengajar sangat ditentukan oleh persiapan yang dilakukan oleh dosennya. Karena dalam tahap persiapan, dosen akan memikirkan dengan baik tindakan seperti apa yang akan dilakukan dalam kegiatan pembalajaran. Selain itu dosen juga akan mempersiapkan perangkat mengajar, rambu-rambunya hingga dirumuskannya silabus, RPS, dan materi ajar. Dengan demikian, demi efektifitas pembelajaran tetap terjaga, maka ada tiga komponen utama yang perlu dan harus diperhatikan oleh setiap dosen yakni: materi ajar, metode ajar, dan media pembelajaran.

Hal ini juga menjadi sangat urgen dalam masa pandemi covid-19. Tanpa adanya materi ajar, metode ajar, dan media pembejaran yang tepat maka pembelajaran akan sulit untuk berjalan dengan efektif. Mengapa? Oleh karena dengan adanya pandemi covid-19 ini maka mengubah banyak hal dalam dunia pendidikan di seluruh dunia termasuk di Indonesia. Perubahan yang paling mencolok adalah berubahnya pembelajaran konvensional atau offline (tatap muka) kepada pembelajaran online atau yang sering disebut daring. Firman dalam penelitiannya mengatakan, "Perubahan pola perilaku tidak hanya sebatas pada aspek sosial tetapi juga terjadi di dunia pendidikan, termasuk pada proses pembelajaran di perguruan tinggi. Tuntutan untuk melaksanakan gerakan social distancing serta adanya kebijakan work from home mengharuskan dosen untuk merancang pembelajaran yang dapat diikuti mahasiswa dari rumah masing-masing" (Firman, 2020: 14-20). Ditambahkan oleh Firman, 
"Menyikapi hal di atas, banyak dosen yang akhirnya mengubah mode pembelajarannya dari pembelajaran konvensional dalam ruang kelas menjadi pembelajaran online yang dapat diikuti mahasiswa dari mana saja. Pembelajaran online ini dilaksanakan baik secara sinkron maupun asinkron menggunakan layanan web maupun aplikasi pembelajaran. Pembelajaran secara sinkron dilakukan melalui konferensi video. Melalui pembelajaran ini dosen dan mahasiswa bertemu dan berkomunikasi secara real time menggunakan applikasi Zoom atau Google Meet" (Firman, 2020: 14-20).

Covid-19 merupakan wabah yang hadir di setiap belahan dunia. Bahkan WHO juga telah menetapkannya sebagai pandemi global. Wabah ini tidak memandang latar belakang, jenis kelamin, tingkatan ekonomi, hingga strata sosial. Bahkan hampir semua profesi dan bidang akhirnya menjadi terganggu karena hadirnya wabah ini. Termasuk di dalamnya adalah sekolah atau kampus-kampus, yang akhirnya memilih untuk meninggalkan cara belajar konvensional dengan pertimbangan keselamatan guru atau dosen dan siswa atau mahasiswa. Seperti yang dikemukakan oleh Damayanti, "Seluruh proses belajar mengajar selama pandemi Covid-19 dilakukan secara online atau dengan mengimplementasikan e-learning. Ini bertujuan untuk menghindari kontak antar manusia" (Luh Sri Damayanti, 2020: 63-82).

Hal ini pula yang dilakukan oleh peneliti ketika mengajar Bahasa Yunani Koine di Sekolah Tinggi Teologi Pelita Dunia. Tidak ada pilihan lain, ketika mengajar mata kuliah ini, peneliti memilih mengajar secara online. Selain karena tidak diperbolehkannya mengajar konvensional, semua mahasiswa juga telah berada di daerah atau kampung mereka masing-masing.

Kondisi inilah yang kemudian membuat peneliti tertarik untuk mencari tahu seberapa jauh efektifkah belajar-mengajar online ini? Oleh karena ada beberapa faktor yang menjadi alasannya. Misalnya: (1) hal ini merupakan pengalaman pertama bagi peneliti untuk mengajar Bahasa Yunani Koine dengan sistem daring, (2) belajar dan mengajar Bahasa Yunani (bahasa pada umumnya) memerlukan interaksi langsung untuk mengintenskan interaksi yang sifatnya praktis, (3) kurangnya sarana dan prasarana yang memadai pada setiap mahasiswa yang belajar, (4) adanya kondisi mendadak berubah, sehingga perkuliahan daring cenderung dilaksanakan tanpa adanya persiapan yang matang, dan (5) metode pembelajaran yang dipilih cenderung kurang memperhatikan situasi dan kondisi mahasiswa.

Pada penelitian ini menggunakan metode kualitatif. The SAGE Encyclopedia of Qualitative Research Methods mengatakan, "Qualitative methods are best for addressing many of the why questions that researchers have in mind when they develop their projects. Where quantitative approaches are appropriate for examining who has engaged in a behavior or what has happened and while experiments can test particular interventions, these techniques are not designed to explain why certain behaviors occur. Qualitative approaches are typically used to explore new phenomena and to capture individuals' thoughts, feelings, or interpretations of meaning and process" (Lisa M. Given, ed., 2008: xxix). Menurut pendapat di atas, metode kualitatif paling baik untuk menangani banyak dari pertanyaan mengapa yang ada dalam pikiran peneliti kapan mereka mengembangkan proyek mereka. Ditambahkan oleh pendapat di atas, pendekatan kualitatif digunakan untuk mengeksplorasi fenomena baru dan menangkap pikiran, perasaan, atau interpretasi individu tentang makna dan proses.

Kemudian dalam buku The Oxford Handbook of Qualitative Research dikemukakan, "Qualitative research commonly requires working with others over an expanse of time 
and producing large amounts of data for analysis while also demanding sustained attention to ethics and values. It is also a creative process-allowing researchers to experiment, play, adapt, learn, and grow along the way" (Patricia Leavy, ed., 2014: 6). Maksudnya, penelitian kualitatif biasanya membutuhkan kerja dengan orang lain selama bentangan waktu dan produksi sejumlah besar data untuk analisis sekaligus menuntut perhatian berkelanjutan terhadap etika dan nilai. Itu juga proses kreatif memungkinkan peneliti bereksperimen, bermain, beradaptasi, belajar, dan tumbuh di sepanjang jalan.

Hal itu juga yang kemudian diterapkan dalam penelitian ini. Di mana penelitian ini mengkombinasi antara tinjauan pustaka yang diolah secara kreatif dengan data atau informasi dari responden yang diramu menjadi sebuah data kualitatif yang kredibel. John Creswell mengatakan, "Tinjauan kepustakaan adalah rangkuman tertulis dari berbagai artikel jurnal, buku dan dokumen-dokumen lain yang mendeskripsikan situasi informasi sebelumnya dan saat ini tentang topik penelitian" (John Creswell, 2015: 170). Dengan demikian diharapkan setiap kesimpulan yang diperoleh dari penelitian ini merupakan kesimpulan yang telah teruji dalam konteks penelitian kualitatif.

\section{B. Pembahasan}

\section{Alasan Belajar Bahasa Yunani Koine}

Bahasa Yunani Koine merupakan mata kuliah wajib atau yang seringkali disebut Mata Kuliah Keahlian (MKK) dalam kurikulum Sekolah Tinggi Teologi yang dikeluarkan oleh Kementerian Agama RI. Mata kuliah keahlian (MKK) yaitu sejumlah mata kuliah yang merupakan substansi kajian bidang ilmu yang menjadi isi program pendidikan akademik pada stratum tertentu. Kompetensi yang diharapkan: (1) Sarjana teologi yang profesional dalam penguasan ilmu dan menerapkannya, (2) menguasai ilmu teologi untuk dapat diaplikasikan pada bidang-bidang kehidupan yang membutuhkannya baik di gereja maupun di masyarakat (Direktorat Jenderal Bimbingan Masyarakat Kristen, Kementerian Agama RI, 2011: 32).

Oleh karena tempat Bahasa Yunani Koine dalam kurikulum STT dan STAK sangat sentral karena tergolong ke dalam kelompok mata kuliah yang substansi dalam kaitannya dengan kajian bidang ilmu dan penerapannya, menjadikan mata kuliah ini wajib dipelajari dan dikuasai oleh setiap mahasiswa teologi. Semua mahasiswa diwajibkan untuk tuntas belajar mata kuliah ini - tentunya dengan nilai minimal B. Bahkan pada Peraturan Akademik STT Pelita Dunia mengatur setiap mahasiswa yang tidak tuntas mata kuliah ini tidak dapat mengikuti mata kuliah Tafsir/Eksegesis Perjanjian Baru dan wajib mengikuti kelas remedial pada semester berikutnya. Dalam penelitian ini, hal ini ditempatkan pada alasan pertama belajar Bahasa Yunani Koine.

Alasan berikutnya belajar Bahasa Yunani Koine untuk menolong dan membantu setiap mahasiswa menafsirkan Alkitab, khususnya PB. Secara substansi, alasan kedua ini jauh lebih krusial dan penting dari alasan sebelumnya. Berdasarkan alasan kedua ini pula membuat Bahasa Yunani Koine wajib dipelajari dan dikuasai oleh setiap orang Kristen. Oleh karena setiap orang Kristen adalah penafsir teks Alkitab dan tanpa adanya pemahaman yang baik tentang bahasa asli Alkitab, maka pasti mereka diperhadapkan dengan banyak sekali kesulitan atau menjadi sangat tergantung kepada terjemahan orang lain. William D. Mounce mengatakan, "My assumption is that you are learning biblical Greek so you can better understand the Word of God and share that understanding with those around you" (William D. Mounce, 2009: x). Artinya Mounce setuju bahwa alasan belajar Bahasa Yunani Koine adalah untuk membuat setiap orang Kristen semakin mudah memahami Firman Tuhan (Alkitab). 


\section{Belajar-Mengajar Bahasa Yunani Koine Pada Situasi Pandemi Covid-19}

Melakukan sesuatu di luar kebiasaan yang sering dilakukan memerlukan sebuah adaptasi dan kreatifitas yang ekstra. Hal ini juga yang dirasakan dan dialami oleh peneliti ketika tiba-tiba pandemi Covid-19 mengubah system perkuliahan dari yang offline atau konvensional menjadi perkuliahan online atau e-learning. Tantangan menjadi besar karena yang diajarkan adalah mata kuliah bahasa, dalam hal ini Bahasa Yunani Koine.

Seorang peneliti dari Universitas Muhammadiyah Surabaya, bernama Sujinah juga meneliti perihal tantangan mengajar bahasa di masa pandemi Covid-19. Sekalipun fokus penelitiannya lebih kepada mengajar bahasa Indonesia namun dalam penelitian ini turut dijadikan sebagai bahan perbandingan. Hasil penelitian Sujinah mengatakan,

"(1) tidak semua pendidik mata pelajaran bahasa Indonesia di sekolah vokasi berlatar belakang keilmuan bahasa Indonesia (2) kreativitas tenaga pendidik dalam memecahkan persoalan dalam pembelajaran Bahasa Indonesia kurang; (3) rendahnya persepsi peserta didik terhadap pembelajaran bahasa Indonesia.(4) solusi yang ditawarkan antara lain berupa pembelajaran dengan menggunakan teknologi gawai dan internet: membuat video rekaman misalnya rekaman membaca puisi, menulis karikatur untuk materi teks anekdot, dan membuat main mapping untuk materi teks eksposisi. Diperlukan penataan kembali guru mata pelajaran Bahasa Indonesia dan peninjauan kurikulum Bahasa Indonesia serta pembekalan mendesain media pembelajan yang inovatif' (Sujinah, 2020: 256271).

Sedangkan Luh Sri Damayanti juga melakukan penelitian khususnya tentang penerapan e-learning dalam mengajar bahasa Inggris di masa pandemi Covid-19. Hasil penelitiannya menemukan, "(1) Google Classroom digunakan oleh sebagian besar responden kemudian diikuti oleh Zoom, Edmodo, WhatsApp, dan YouTube, (2) aksesibilitas, fitur komunikasi, media yang didukung, jenis penilaian yang disediakan, desain, dan harga menjadi pertimbangan bagi responden dalam memilih media elearning, (3) ketidakmerataan akses internet menjadi tantangan terbesar bagi responden dalam menyelenggarakan e-learning, tetapi mereka sepakat bahwa pelaksanaan e-learning memberikan waktu dan tempat yang fleksibel untuk belajar" (Luh Sri Damayanti, 2020: 63-82).

Pada dua penelitian di atas yang dilakukan oleh Sujinah dan Damayanti terhadap belajar-mengajar bahasa Indonesia dan bahasa Inggris di tengah-tengah pandemi Covid-19 memberikan beberapa informasi yang penting guna membuat pembelajaran berjalan lebih efektif. Misalnya seperti Sujinah menemukan beberapa problem serius yang dihadapi, yakni: guru yang tidak berkompeten pada bidangnya, guru kurang kreatif, rendahnya persepsi peserta didik. Itulah sebabnya dalam penelitian tersebut, Sujinah menawarkan solusi kepada setiap guru bahasa Indonesia untuk membuat video rekaman yang berisi penjelasan materi, karena menurutnya ini jauh lebih efektif.

Sedangkan penelitian Damayanti menyimpulkan bahwa dalam mengajar bahasa Inggris di masa pandemi Covid-19 jauh lebih efektif menggunakan Google Classroom, Zoom, Edmodo, WhatsApp, dan YouTube. Alasan menggunakan elearning di atas adalah aksesibilitas, fitur komunikasi, media yang didukung, jenis penilaian yang disediakan, desain, hingga harga yang terjangkau. Akan tetapi tidak meratanya akses jaringan internet menjadi tantangan terbesar bagi penggunaan elearning. 
Ketika peneliti mengajar Bahasa Yunani Koine di masa pandemi Covid-19, beberapa strategi mengajar yang diterapkan, seperti: membuat video rekaman penjelasan materi, mengadakan kuliah online lewat zoom dan google meet, menyampaikan materi kuliah lewat WhatsApp group dan Email.

Membuat video rekaman penjelasan materi. Ini merupakan cara atau metode yang paling dominan dilakukan oleh peneliti ketika mengajar Bahasa Yunani Koine di masa pandemi Covid-19. Dengan menggunakan aplikasi Active Presenter, dibuatlah rekaman penjelasan materi yang telah lebih dahulu di buat dalam bentuk power point dan dibagi berdasarkan tense verba Bahasa Yunani Koine, khususnya modus Indikatif. Rekaman video ini dibatasi dengan hanya berdurasi sekitar 15-20 menit. Setiap video rekaman selanjutnya disimpan di Google Drive dan selanjutnya linknya dishare kepada mahasiswa untuk dinonton dan dipelajari melalui WhatsApp dan Email.

Mengadakan kuliah online lewat zoom dan google meet. Selain membuat rekaman video, peneliti juga mengadakan pertemuan online lewat google meet dan zoom. Pertemuan ini bertujuan untuk mengkonfirmasi apakah materi yang telah disampaikan sebelumnya lewat WhatsApp dan Email. Akan tetapi seringkali akses jaringan internet menyulitkan banyak mahasiswa untuk bergabung dan mengikuti kelas. Oleh karena mayoritas mahasiswa yang belajar berada di daerah-daerah seperti Kalimantan, NTT, Sulawesi Selatan, dan Nias.

Menyampaikan materi kuliah lewat whatsapp group dan email. Biasanya materi kuliah baik video rekaman maupun modul kuliah disampaikan lewat WhatsApp dan email. Tidak hanya itu saja, bahkan Soal Ujian Tengah Semester (UTS) dan Ujian Akhir Semester (UAS) juga disampaikan lewat media ini. Soal UTS dan UAS akan dikerjakan oleh Mahasiswa dengan batas waktu maksimal dua hari kemudian dikirim kembali lewat media yang sama. Ada yang mengirim dalam bentuk foto dan beberapa juga dalam bentuk file, seperti word dan pdf.

\section{Efektifitas Belajar-Mengajar Bahasa Yunani Koine pada Pandemi Covid-19}

Seberapa efektifkah belajar-mengajar Bahasa Yunani Koine dalam masa pandemi Covid-19 ini? Adapun maksud efektif dalam penelitian ini adalah materi kuliah yang disampaikan dapat dengan mudah dipahami oleh mahasiswa, mahasiswa dapat mengerjakan tugas, latihan dan soal UTS dan UAS dengan jujur dan tanpa menyontek.

Peneliti telah menyebarkan kuesioner yang berisi pertanyaan-pertanyaan yang berkaitan dengan judul penelitian ini. Penelitian ini dilaksanakan pada tanggal 1-14 Agustus 2020. Responden adalah mahasiswa Semester 2 Program Studi Teologi dan Pendidikan Agama Kristen (PAK). Adapun jumlah responden yang memberikan respons berjumlah 18 orang. Berikut akan disampaikan beberapa presentase efektifitas belajar-mengajar Bahasa Yunani Koine di masa pandemi Covid-19 berdasarkan jawaban mahasiswa yang telah mengikuti kelas ini. 
Grafik 1

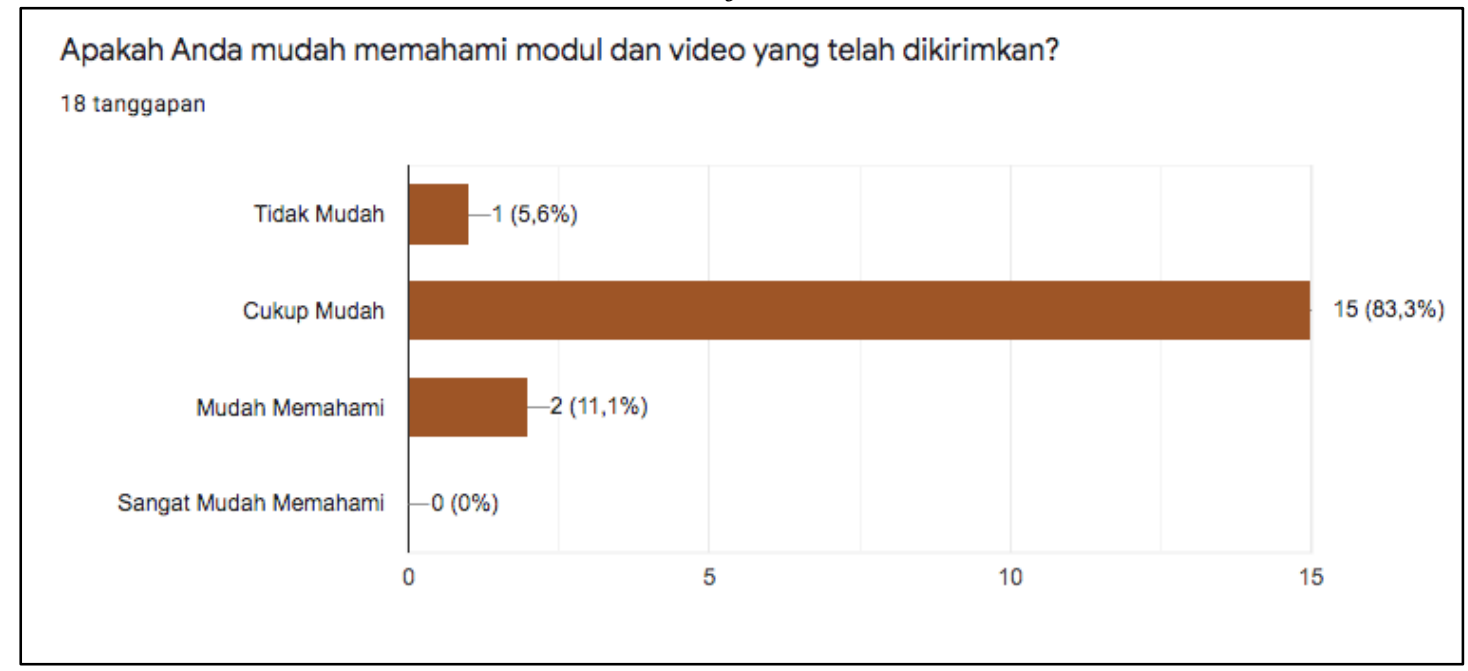

Pada grafik pertama di atas memberikan sebuah konfirmasi tentang tingkat kesulitan memahami setiap materi yang disampaikan lewat rekaman video dan modul. Berdasarkan jawaban responden maka diperoleh kesimpulan bahwa peneliti perlu memperbaiki banyak hal dalam meningkatkan tingkat kemudahan mahasiswa memahami materi. Hal ini dikonfirmasi dari tidak adanya responden yang menjawab materi sangat mudah dipahami, baik dalam bentuk video maupun modul. Responden yang mengatakan materi mudah dipahami hanya $11,1 \%$ saja atau sekitar 2 responden saja. Mayoritas responden setuju bahwa materi cukup mudah dipahami dengan tingkat presentase mencapai $83,3 \%$ atau sekitar 15 responden. Materi yang cukup mudah dipahami sebenarnya tidak lebih baik karena cenderung lebih dekat kepada tidak mudah dipahami. Bahkan ada 1 responden yang menjawab tentang materi yang tidak mudah dipahami.

\section{Grafik 2}

Sejauh mana tingkat pemahaman tentang Bahasa Yunani Koine 2

18 tanggapan

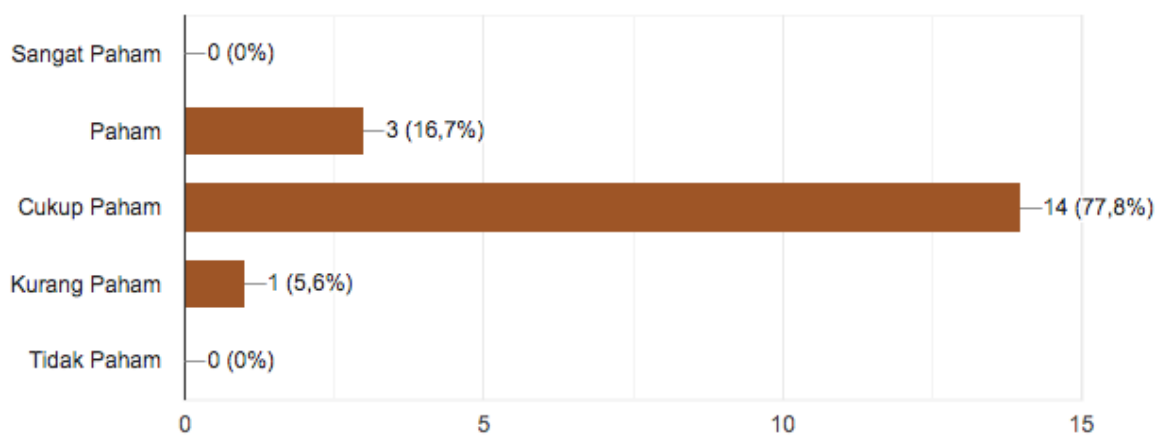

Hal yang tidak jauh berbeda ketika peneliti mengajukan pertanyaan: sejauh mana tingkat pemahaman Anda tentang Bahasa Yunani Koine? Tidak ada satu responden pun yang menjawab bahwa mereka sangat paham. Hanya 3 responden atau sekitar $16,7 \%$ yang menjawab paham. Sekali lagi mayoritas responden berada tempat tengah atau cenderung ke tingkatan yang rendah. Di mana terdapat 14 responden atau sekitar 
$77,8 \%$ yang menjawab cukup paham. Terdapat 1 responden atau sekitar 5,6 \% yang menjawab kurang paham. Tidak ada responden yang menjawab tidak paham.

Grafik 3

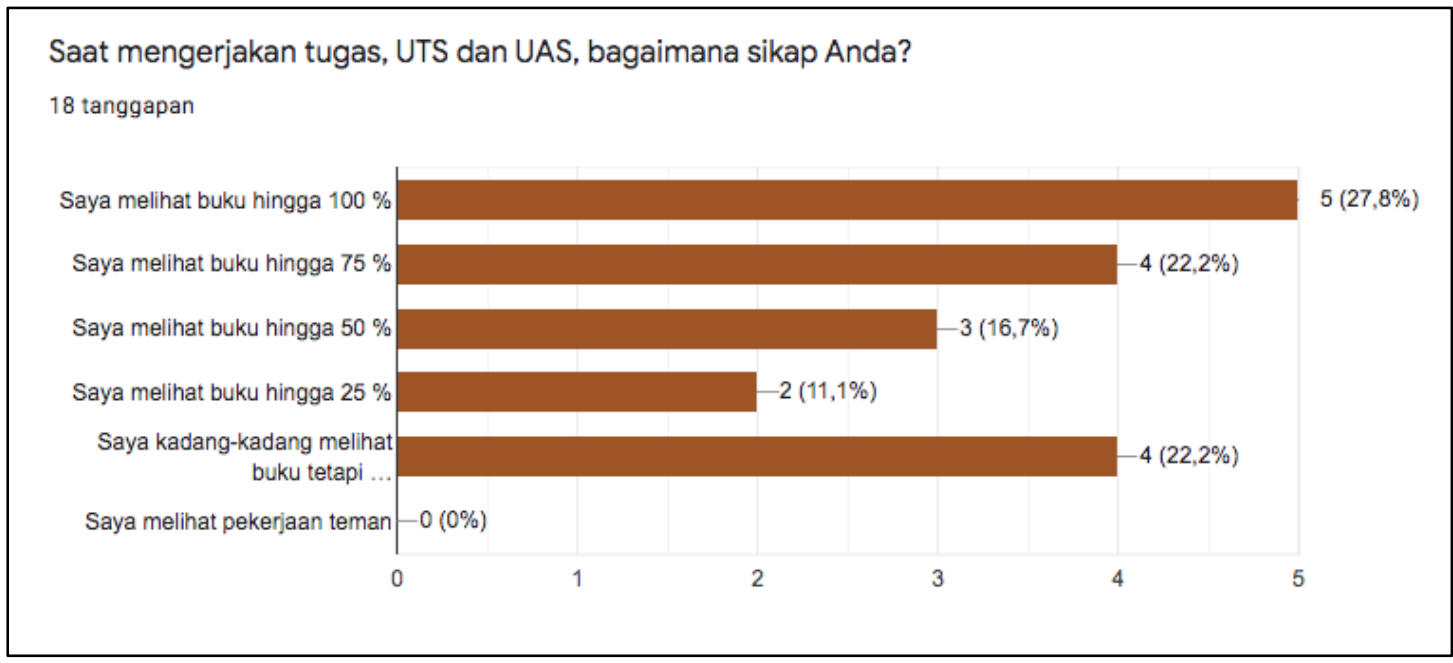

Data atau informasi yang ditunjukkan pada grafik ketiga juga sangat menyedihkan. Sekaligus memberikan penegasan betapa belajar Bahasa Yunani Koine secara online pada masa pandemi memiliki tingkat efektifitas yang rendah. Mengapa? Oleh karena mayoritas mahasiswa yang mengikuti kelas ini ketika mengerjakan tugas, UTS, dan UAS masih melihat buku, bahkan jumlahnya mencapai 5 orang atau sekitar 27,8\%. Selanjutnya secara berturut-turut diikuti: 4 orang atau sekitar $22,2 \%$ yang melihat buku hingga $75 \%, 3$ orang atau sekitar 16,7\% yang melihat buku hingga 50\%, dan 2 orang atau sekitar $11,1 \%$ yang melihat buku hingga $25 \%$. Bahkan berdasarkan jawaban responden menunjukkan hanya 4 orang atau sekitar $22,2 \%$ yang kadangkadang melihat buku.

\section{Grafik 4}

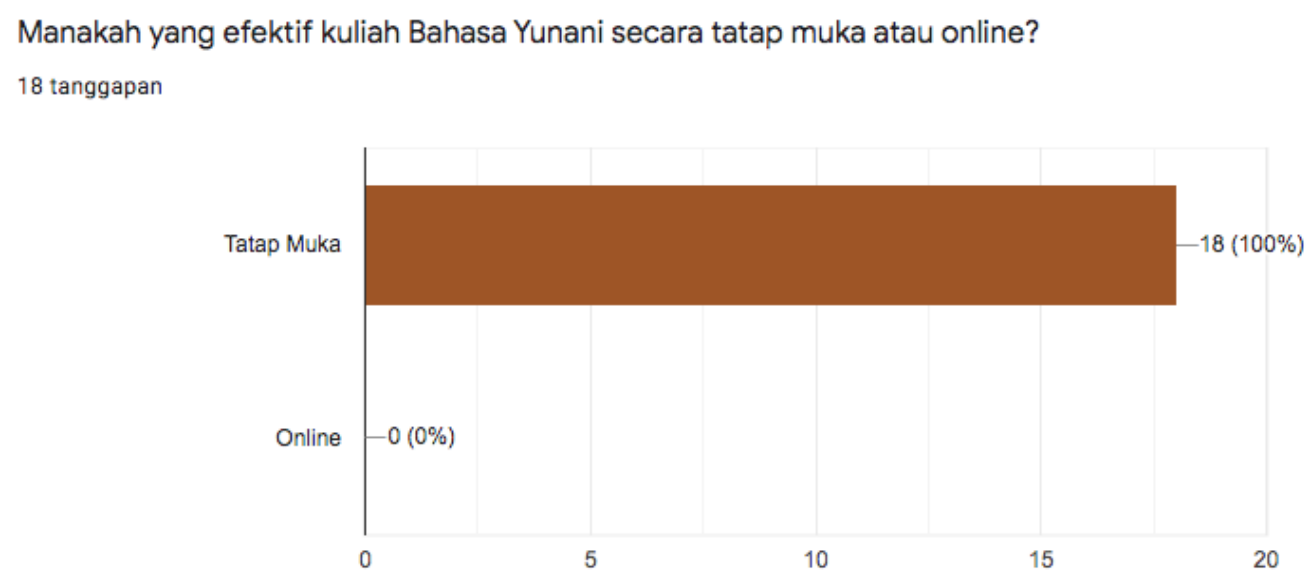

Berdasarkan grafik terakhir atau keempat di atas memberikan konfirmasi betapa belajar-mengajar Bahasa Yunani Koine lebih efektif dipelajari secara offline atau dengan cara konvensional. Terdapat $100 \%$ responden setuju bahwa mata kuliah ini lebih efektif dipelajari secara offline atau tatap muka langsung. Ketika peneliti mencoba mencari tahu alasannya dan bertanya kepada beberapa responden. Adapun 
alasan responden, seperti: kuliah tatap muka lebih efektif karena mereka dapat bertanya langsung kepada dosen apabila ada materi yang tidak mereka pahami; kuliah tatap muka lebih efektif karena terkadang kuliah online terkendala dengan jaringan internet dan kuota internet habis dan tidak punya uang untuk membeli; kuliah tatap muka lebih efektif karena dosen dapat lebih maksimal membimbing dan mengontrol mahasiswa mengerjakan tugas, UTS dan UAS.

\section{Penutup}

Berdasarkan penelitian yang telah dilakukan terhadap efektifitas belajarmengajar Bahasa Yunani Koine selama masa pandemi Covid-19, maka didapatkan beberapa kesimpulan.

Pertama, belajar-mengajar Bahasa Yunani Koine pada masa pandemi Covid-19 kurang efektif. Kesimpulan ini diambil berdasarkan beberapa indikator, seperti: mahasiswa masih diperhadapkan pada kesulitan untuk memahami materi kuliah yang telah dibuat dalam bentuk video dan modul; belum mayoritas mahasiswa memahami materi Bahasa Yunani Koine, mahasiswa yang melihat buku saat mengerjakan tugas, UTS dan UAS masih sangat dominan, dan mayoritas mahasiswa menginginkan kuliah offline daripada kuliah online dengan berbagai macam alasan yang mereka kemukakan.

Kedua, beberapa faktor yang dapat dijadikan penyebab utama kurang efektifnya belajar-mengajar Bahasa Yunani Koine di masa pandemi Covid-19, antara lain: sarana dan prasarana yang meliputi jaringan internet belum mendukung perkuliahan secara daring; karakteristik belajar bahasa Yunani memang cenderung lebih mudah dipelajari secara offline; dan tingkat pemahaman mahasiswa yang rendah dan belum bisa belajar mandiri dan bertanggung jawab.

Ketiga, beberapa solusi supaya belajar-mengajar Bahasa Yunani Koine bisa lebih efektif. Misalnya: pemerintah dan pihak sekolah harus menyediakan sarana dan prasarana kuliah online kepada mahasiswa dan dosen; dosen harus lebih kreatif dan inovatif lagi dalam mempersiapkan materi kuliah; mahasiswa harus lebih dewasa dan bertanggung jawab dalam belajar. Dengan demikian belajar-mengajar Bahasa Yunani Koine dapat berjalan jauh lebih efektif.

\section{Referensi}

Creswell, John. Riset Pendidikan: Perencanaan, Pelaksanaan, Dan Evaluasi Riset Kualitatif Dan Kuantitatif. Kelima. Yogyakarta: Pustaka Pelajar, 2015.

Damayanti, Luh Sri. "Implementasi E-Learning Dalam Pembelajaran Bahasa Inggris Di Pendidikan Tinggi Pariwisata Di Bali Selama Pandemi Covid-19." In Journey (Journal Of Tourismpreneurship, Culinary, Hospitality, Convention And Event Management), 2:63-82, 2020.

Firman, Firman. "Dampak Covid-19 Terhadap Pembelajaran Di Perguruan Tinggi." BIOMA: Jurnal Biologi dan Pembelajarannya 2, no. 1 (2020): 14-20.

Given, Lisa M., ed. The SAGE Encyclopedia of Qualitative Research Methods Volume $1 \& 2$. New Delhi, India: SAGE Publication, 2008.

Leavy, Patricia, ed. The Oxford Handbook of Qualitative Research. New York: Oxford University Press, 2014.

Manalu, Tuti Waty Boang, Christina Metallica Samosir, and Ronny Gunawan. "HUBUNGAN ANTARA PERSIAPAN MENGAJAR GURU DENGAN DAYA TANGKAP SISWA PADA MATA PELAJARAN PENDIDIKAN AGAMA KRISTEN KELAS XI DAN XII DI SEKOLAH SMA 4 PSKD PANGLIMA POLIM." REGULA FIDEI: Jurnal Pendidikan Agama Kristen 4, 
no. 2 (2019): 111-123.

Mounce, William D. Basics of Biblical Greek Grammar. Grand Rapids, Michigan: Zondervan Publishing House, 2009.

Sujinah, Sujinah. "Tantangan Dan Solusi Pembelajaran Bahasa Indonesia Di Era Covid-19." Stilistika: Jurnal Pendidikan Bahasa dan Sastra 13, no. 2 (2020): 256-271.

Panduan Kurikulum Stratum Satu (S1) Prodi Teologi Kependetaan STT Dan STAK Di Indonesia. Jakarta: Direktorat Jenderal Bimbingan Masyarakat Kristen, Kementerian Agama RI, 2011. 